\title{
Procurement Risk Management in International Supply Structures. The Case of Italian Manufacturing Companies
}

\author{
Maria Rosaria Marcone* \\ Polytechnic University of Marches, Italy
}

*Corresponding author: Maria Rosaria Marcone, Department of Management, Polytechnic University of Marches, Ancona, Italy.

Received Date: February 06, 2019

Published Date: February 13, 2019

\section{Introduction}

In the current economic contexts, we are witnessing profound changes in the processes of structuring supply chains internationally. On the one hand, supply chains are constituted in new ways in certain geographical areas and we see real relocalizations of supply chains that are differentially specialized in the various world locations. On the other hand, supply chains, even those that connote made in Italy, are internationalized as a whole [1-4].

Another significant phenomenon is the repositioning in the international supply chain by the Italian knitwear firms operating in the business to consumer (B2C) markets. In recent years there have been many companies that have modified the content of the strategies and characteristics of their organizational structure in order to protect new "interstitial spaces" (or micro-segments) in international markets.

A further starting point for reflection and managerial investigation is the emergence of new buyer-supplier relationships in new product development (NPD) processes in creative Italian sectors. Industrial innovation based on the involvement of suppliers in specific and experimental 'design-engineering' processes that highlight the need for buyers and suppliers to structure international bargaining between bargaining and relational governance in a new way.

As regards the methodology adopted, a longitudinal analysis has been followed for some time, making use of the observation in the field of the international strategies of ten excellent companies in the sector: the management phenomena that emerge in the various managerial areas are interpreted; we monitor the balance sheet data and the competitive performance of companies that excel in the Italian knitwear sector.

\section{Theoretical Framework}

The purpose of this research field is to understand how the consistency between objective and perceived competitive uncertainty might affect supply chain flexibilities that cope with supply chain risk.

Factors including rapid technological development, the advent of innovative openness processes involving sub-sectors belonging to diversified supply chains, shorter product life cycles, more diversified and customized, demand and fierce marketing competition, make today's business model increasingly unpredictable and risky.

Some firms develop effective supply chain risk management (SCRM) strategies in response to the uncertainty of competitive challenges, such as NPD activities (because of the life cycle of the technology incorporated in the products and of the customized engineering fashion collections for each order), product-portfolio assortments, multi-sourcing strategies.

To the extent that flexibility constitutes an adaptive response to environmental uncertainty and operational risks [5,6], it is important to understand when and how such a response actually arises.

H.1 - It is hypothesized that the flexibility of designmanufacturing systems in creative knitwear firms is greatly increased in current technological contexts.

In an accelerated competitiveness of the international structures of the offer, it is possible to think that it is an improvised manner. Extemporaneous inter-organizational collaborations in a 'supply side sense' thus becomes inevitable and has increasingly triggered scholarly interest due to its potential value in building 
innovative knowledge and innovative capabilities in diversified supply chains that relate to each other in an unthinkable manner to the recent past. Tale improvisation is a key factor at the center of the broad concept of resource slack, intended to refer to more traditional approaches of analysis presented in the international managerial literature and to accept conceptual analysis tools and interpretations proposed by studies that are still experimental. The first approach was presented by the prior literature recognizing the important role of slack resources in intangible operational activities in converting improvised creative activities of the style office and the engineering activities of fashion collections into enhanced innovation capability. In the most recent interpretations resource slack manifests in the context of improvisation by helping the firm to interrupt a dysfunctional momentum and work out innovative solutions [7-9].

H.2 - One can hypothesize that improvisation enhances a firm's innovation capability more when a firm has greater resource slack.

\section{Methodology}

\section{Case analysis}

An interpretative, qualitative approach - utilizing selected multi-case study interviews (Yin, 2008) such as the primary data collection method - is chosen because it helps to navigate and understand the complex issues that are associated with the data quality concept, and its relation to the factors involving managerial practices to implement facilities in modern relationships within the international supply chain. 'Oriented case studies' investigate the issue within a real-life context, drawing on the reviews of a number of sources, and provides the means to review theory and practice iteratively $[10,11]$ Multiple cases ensure that common patterns are identified rather than generalized from what might be change occurrences [10].

\section{Supplier-Buyer Relationships in Innovation Processes}

More recent NPD studies start to show challenges of managing suppliers in a buyer's innovation process.

According to RBV two types of flexibility particularly relevant to supply chain management are logistics flexibility involving physical resources and relationship flexibility involving relational resources [12].

Concerning H2, it was found that the innovative situations of firms characterized markedly by this gap are those destined to be more predictable to success: it cannot be overlooked that most of the companies of the sample investigated live such innovative challenges.

It is obvious that the optimal decision making in purchasing risk management under uncertainty should incorporate many potential risk sources, such as demand chain, operational flow risks, supply yield, etc. (see the points a and $b$ in the figure 1 ).
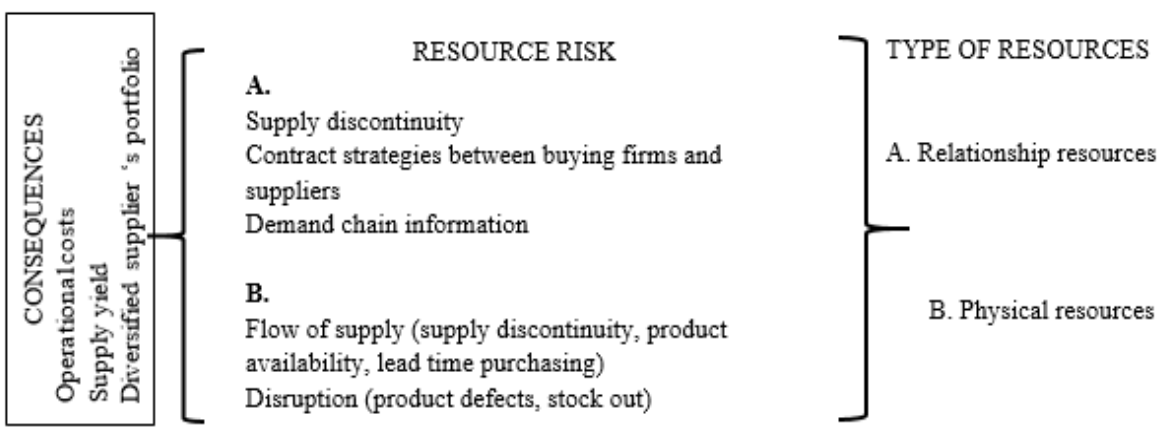

Source: Our elaboration based on empirical research.

Figure 1: Procurement risk management: types of risk and consequences/challenges.

There are many factors that determine the risk of procurement activities and that generate economic-financial effects. The factors that cause an unreliable yield of the supply are as follows: because of the supplier's limited production capability, they could not deliver all the products on time; not all the supplier's products meet the requirement, so only a part of the ordered materials can be processed.

Operational risk is the potential loss due to the lack of good coordination of supply chain activities among different parties in supply chain. Disruption risk is mainly referred to the loss from unexpected event such as malfunction of equipment.

Diversified supplier's portfolio is a multiple-sourcing strategy that is particularly requested by knitwear companies, which in NPD activities involve suppliers, also belonging to other productive sectors, of innovative yarns composed of highly technological materials, in order to create an offer dedicated to micro- market segments composed of customers (retailers or end customers) who request knitted garments suitable for new opportunities for use.

\section{Concluding Observations}

This investigative work promotes research methodological approaches to analyze different uncertainty scenarios for the future.

Perceived competitive uncertainty is also the primary driver of supply chain flexibility even in firms that belong to a sector, that of knitwear, belonging to the super luxury Italian fashion system.

It is obvious that the optimal decision making in purchasing risk management under uncertainty should incorporate many potential risk sources, such as demand chain uncertainty, operational flow risk, supply chain disruption effects, supply yield, etc. 
It has been investigated under which of the competitive environmental conditions the firms implement different types of supply chain risk management (SCRM) strategies (logistics flexibility and relationship flexibility) and also supply chain risk management procedures [13].

These procedures must be suitable to allow them to maintain the competitive differential against various competitors at least on critical success factors, such as product differentiation, the ability to manage complex order cycles, use efficiently and on a small scale of new process technologies, the use of new materials, etc.

This new and more favorable competitive positioning both in the business markets and in the international consumer markets has been successfully achieved by those companies that have been able to change their position regarding the "global supply chains". Precisely their particular ability to identify in which segments of the sector operate, in these years in which the international supply system is being reorganized, has been the element that has allowed non-large companies to create differential assets in the competitive context.

\section{Acknowledgement}

None.

\section{Conflict of Interest}

No conflict of interest.

\section{References}

1. Arregle JL, Beamish PW, Hébert L (2009) The regional dimension of MNEs' foreign subsidiary localization. Journal of International Business Studies 40(1): 86-107.
2. Cantwell J (2009) Location and the multinational enterprise. Journal of International Business Studies 40(1): 35-41.

3. Miller SR, Eden L (2006) Local density and foreign subsidiary performance. Academy of Management Journal 49(2): 341-355.

4. Rugman AM, Verbeke A (2004) A perspective on regional and global strategies of multinational enterprises. Journal of International Studies 35(1): 3-18.

5. Sreedevi R, Saranga H (2017) Uncertainty and supply risk: the moderating role of supply chain flexibility in risk mitigation. International Journal of Production Economics 193(29): 332-342.

6. Tang C, Tomlin B (2008) The power of flexibility for mitigating supply chain risks. International Journal of Production Economics 116(1): 1227.

7. Johannessen IA, Mcarthur PW, Jonassen JR (2015) Informal leadership redundancy: Balancing structure and flexibility in subsea operations. Scandinavian Journal of Management 31(3): 409-423.

8. Saemundsson RJ, Candi M (2017) Absorptive capacity and the identification of opportunities in new technology-based firms. Technovation 64-65: 43-49.

9. Lin S (2018) The structural characteristics of innovation ecosystem: a fashion case. European Journal of Innovation Management 21(4): 620 635

10. Eisenhardt KM, Schoonhoven CB (1996) Resource-based view of strategic alliance formation: Strategic and social effects in entrepreneurial firms. Organization Science 7(2): 136-150.

11. Henneberg SC, Mouzas S, Naudé P (2010) Sense-making and management in business networks: Some observations, considerations, and a research agenda. Industrial Marketing Management 39(3): 355360.

12. Yin RK (2003) Applications of case study research $\left(2^{\text {nd }}\right.$ edn) SAGE Publications, Thousand Oaks, USA.

13. Ellram LM (1996) The use of the case study method in logistics research. Journal of Business Logistics 17(2): 93-138. 